\title{
Pichia lachancei sp. nov., associated with several Hawailan plant species
}

\author{
Herman J. Phaff, ${ }^{1}$ William T. Starmer ${ }^{2}$ and Cletus P. Kurtzman ${ }^{3}$ \\ Author for correspondence: Herman J. Phaff. Tel: +1 530752 1238. Fax: +1 5307524759 \\ e-mail: hjphaff@ucdavis.edu
}

\footnotetext{
Department of Food Science and Technology, University of California, Davis, CA 95616, USA

2 Department of Biology, Syracuse University, Syracuse, NY 13244, USA

3 Microbial Properties Research, National Center for Agricultural Utilization Research, Agricultural Research Service, us Department of Agriculture, Peoria, IL 61604, USA
}

\begin{abstract}
A description is given of Pichia lachancei sp. nov., a new species of yeast that occurs in association with several Hawaiian plant species of the genera Tetraplasandra, Cheirodendron and Clermontia. The new species is heterothallic and occurs in nature in the haploid as well as the diploid state. Upon conjugation of complementary mating types, zygotes are formed that reproduce by budding as diploid cells. When placed on sporulation medium, four hat-shaped spores are produced which are rapidly released from the ascus. Phylogenetic analysis showed that $P$. lachancei is most closely related to Pichia rhodanensis and Pichia jadinii. The diploid type strain of P. lachancei, isolated from rotting bark of Tetraplasandra hawaiiensis on the island of

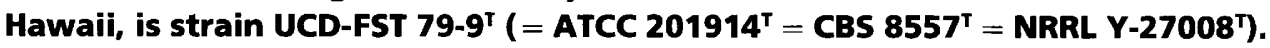

Keywords: Pichia lachancei sp. nov., phylogenetic analysis, large subunit rDNA analysis

\section{INTRODUCTION}

During explorations in 1973 and 1978 of the yeast biota associated with native Hawaiian plants, 18 strains of a species representative of the yeast genus Pichia Hansen emend. Kurtzman were recovered from rotting bark and fruits of several endemic plant species on the island of Hawaii. Attempts to identify these strains by means of the available keys of Kurtzman (1984, 1998) and Barnett et al. (1990) failed to give satisfactory matches with known species.

Further studies involving rDNA analysis confirmed that the isolates represented a new species. Phylogenetic placement of the new species was made by comparing the nucleotide sequence of the speciesspecific large subunit (LSU) rDNA region D1/D2 for the type strain with sequences from all other currently recognized ascomycetous yeasts (Kurtzman \& Robnett, 1997, 1998).

We propose to name the new species Pichia lachancei, honouring Marc-André Lachance for his many con-

Abbreviations: LSU, large subunit; YM, yeast extract/malt extract agar. The GenBank accession numbers for the sequences reported in this paper are shown in Table 2. tributions to the knowledge of natural habitats of yeasts.

\section{METHODS}

Strain isolation. Samples of moist rotting bark or exudate were collected in sterile containers from branches of Tetraplasandra hawaiiensis Gray, Cheirodendron (Araliaceae) Nutt. ex Seem sp. and from decaying fruit of Clermontia (Campanulaceae) Gaud. sp. along Wright Road through the Olaa Tract of Hawaii Volcanoes National Park, Hawaii and several other locations on the island of Hawaii. Samples were streaked on the same day as they were collected on acidified (to $\mathrm{pH} 3.8$ with $1 \mathrm{M} \mathrm{HCl}$ ) yeast extract/malt extract agar (YM; Difco) and incubated at approximately $25^{\circ} \mathrm{C}$. Pure cultures were obtained by re-streaking on YM agar. Morphological and physiological characteristics of the isolates were determined by methods currently used in yeast taxonomy (Yarrow, 1998). Among the many strains isolated from the above sources, 18 strains were representative of $P$. lachancei (Table 1).

Ascospore isolation. Single ascospores were isolated from individual four-spored asci with the aid of a micromanipulator.

DNA base composition. Nuclear DNA base composition determination of the type strain was carried out by the buoyant density method in $\mathrm{CsCl}$ as described by Price $e t$ al . (1978).

DNA isolation, PCR, sequencing reactions and sequence analysis. Protocols for nuclear DNA isolation, symmetrical 
Table 1. Strain numbers, host plants and ploidy of $P$. lachancei isolates

All strains were collected at various locations on the island of Hawaii, Hawaii.

\begin{tabular}{|c|c|c|}
\hline Strain* & Host plant & Ploidy \\
\hline UCD 73-506.1 & Cheirodendron rotting bark with larvae & Unknown \\
\hline UCD 73-507.1 & Cheirodendron rotting bark with larvae & Unknown \\
\hline UCD 73-591.1 & Cheirodendron rotting bark with larvae & Unknown \\
\hline UCD 73-593.1 & Cheirodendron rotting bark & Unknown \\
\hline UCD 73-738.2 & Tetraplasandra rotting bark & Diploid \\
\hline UCD 73-744.1 & Cheirodendron rotting bark & Unknown \\
\hline S 78-352.1 (= UCD 79-2) & Tetraplasandra rotting bark & $\mathrm{h}^{+}$ \\
\hline S 78-353.1 (= UCD 79-3) & Tetraplasandra rotting bark & $\mathrm{h}^{+}$ \\
\hline S 78-354.1 (= UCD 79-4) & Tetraplasandra rotting bark & $\mathbf{h}^{-}$ \\
\hline S 78-354.2(= UCD 79-5) & Tetraplasandra rotting bark & $\mathrm{h}^{-}$ \\
\hline $\mathrm{S} 78-376.2^{\mathrm{T}}\left(=\mathrm{UCD} 79-9^{\mathrm{T}}\right)$ & Tetraplasandra rotting bark & Diploid \\
\hline UCD $79-10$ & Single spore isolate from UCD $79.9^{\mathrm{T}}$ & $\mathrm{h}^{+}$ \\
\hline UCD 79-11 & Single spore isolate from UCD $79.9^{\mathrm{T}}$ & $\mathrm{h}^{-}$ \\
\hline UCD $79-12$ & Single spore isolate from UCD $79.9^{\mathrm{T}}$ & $\mathrm{h}^{-}$ \\
\hline UCD 79-13 & Single spore isolate from UCD $79.9^{\mathrm{T}}$ & $\mathrm{h}^{+}$ \\
\hline S 78-385.1 & Clermontia decaying fruit & $\mathrm{h}^{+}$ \\
\hline S 78-347.1 & Cheirodendron rotting bark & Unknown \\
\hline S 78-383.1 & Cheirodendron rotting bark & Unknown \\
\hline S 78-441.1 & Cheirodendron rotting bark & Unknown \\
\hline S 78-361.2 & Tetraplasandra rotting bark & Unknown \\
\hline S 78-387.3 & Clermontia decaying fruit & Unknown \\
\hline S 78-362.3 & Tetraplasandra rotting bark & Unknown \\
\hline
\end{tabular}

*UCD ( = UCD-FST), Culture collection of the Department of Food Science and Technology, University of California, Davis, CA, USA. Designations that begin with S were assigned by W. T. Starmer.

amplification of LSU region D1/D2 (nucleotides 63-642 for Saccharomyces cerevisiae) by PCR and cycle sequencing of both strands of this region with the Taq DyeDeoxy Terminator Cycle Sequencing kit (Applied Biosystems) were previously given in detail (Kurtzman \& Robnett, 1997). Sequence data were visually aligned with QEDIT 2.15 (SemWare). Phylogenetic relationships were calculated with a Power Macintosh $8500 / 120$ by the maximum-parsimony program of PAUP 3.1.1 (Swofford, 1993) with a heuristic search employing both simple and random sequence additions. Confidence limits for phylogenetic trees were estimated from bootstrap analyses (100 replications). Schizosaccharomyces pombe was the designated outgroup in the analyses.

Nucelotide sequence accession numbers. GenBank accession numbers are given in Table 2.

\section{RESULTS AND DISCUSSION}

On the basis of our phylogenetic analysis of nucleotide sequences from $\mathrm{LSU}$ region $\mathrm{D} 1 / \mathrm{D} 2, P$. lachancei represents a novel species of the genus Pichia. It is a member of the Pichia bimundalis clade and is located basal to $P$. rhodanensis and $P$. jadinii (Fig. 1). $P$. lachance $i$ can be differentiated phenotypically from $P$. rhodanensis and $P$. jadinii by its inability to assimilate maltose, trehalose and melezitose and by its lack of growth at $37^{\circ} \mathrm{C}$.

\section{Latin diagnosis of Pichia lachancei sp. nov.}

In YM (Difco) liquido post dies 5 ad $30^{\circ} \mathrm{C}$, cellulae ovoideae vel elongatae, 3-5 × 4-12 $\mu \mathrm{m}$, singulae, binae aut catenis brevis; sedimentum; pellicula tenuis. Cultura in agaro malti post unem mensem ad $25^{\circ} \mathrm{C}$ griseola, butyrosa vel mollis, umbonata, rugosa, semi nitida, margo pseudomycelialis. In agaro farinae Zea mays post dies 14 pseudomycelium eumorphum. Cultura heterothallica. Asci habentes 4 sporos pileiformae in quoque asco; asci rumpunter. Fermentatio glucosi, saccharosi et raffinosi (tarda). Glucosum, saccharosum, cellobiosum, raffinosum, D-xylosum, L-rhamnosum, ethanolum, glycerolum, D-mannitolum (tarde), Dglucitolum, salicinum, methyl $\beta$-D-glucosidum, glucono$\delta$-lactonum, acidum lacticum, acidum succinicum, acidum citricum, ethyl acetas assimilantur at non galactosum, L-sorbosum, maltosum, trehalosum, lactosum, melibiosum, melezitosum, inulinum, amylum solubile, L-arabinosum, D-arabinosum, D-ribosum, erythritolum, ribitolum, galactitolum, methyl $\alpha-D$-glucosidum, 2-ketogluconatum, 5-ketogluconatum, mesoinositolum, glucosaminum, N-acetyl-glucosaminum, hexadecanum, 2-propanolum, nec acetonum. Kalium nitricum, natrium nitrosum non assimilantur; ethyl aminum, lysinum, cadaverinum assimilantur. Ad crescentiam vitaminae additae necessariae sunt. Crescere potest in $30^{\circ} \mathrm{C}$ at non in $37^{\circ} \mathrm{C}$. $\mathrm{G}+\mathrm{C}$ acidi deoxyribo- 
Table 2. Strains of Pichia lachancei and reference species compared

T, Type strain; NT, neotype strain.

\begin{tabular}{|c|c|c|c|c|}
\hline \multirow[t]{2}{*}{ Species } & \multicolumn{3}{|c|}{ Strain designation* } & \multirow[t]{2}{*}{ GenBank no. } \\
\hline & CBS & NRRL & UCD-FST & \\
\hline 'Hansenula misumaiensis' & $8062^{\mathrm{T}}$ & $Y-17389^{\mathrm{T}}$ & & U73581 \\
\hline Pichia americana & $5644^{\mathrm{T}}$ & $Y-2156^{\mathrm{T}}$ & & U73575 \\
\hline Pichia amylophila & $7020^{\mathrm{T}}$ & YB-1287 & & U73577 \\
\hline Pichia bimundalis & $5642^{\mathrm{T}}$ & $Y-5343^{T}$ & & U73574 \\
\hline Pichia euphorbiae & $8033^{\mathrm{T}}$ & $Y-17232^{\mathrm{T}}$ & & U73580 \\
\hline Pichia euphorbiiphila & $8083^{\mathrm{T}}$ & $\mathrm{Y}-12742^{\mathrm{T}}$ & & U73582 \\
\hline Pichia fabianii & $5640^{\mathrm{T}}$ & $\mathrm{Y}-187 \mathrm{I}^{\mathrm{T}}$ & & U73573 \\
\hline Pichia jadinii & $1600^{\mathrm{T}}$ & $\mathrm{Y}-1542^{\mathrm{T}}$ & & U73570 \\
\hline Pichia japonica & $7209^{\mathrm{T}}$ & YB- $2750^{\mathrm{T}}$ & & U73579 \\
\hline \multirow[t]{3}{*}{ Pichia lachancei } & $8557^{T}$ & $\mathrm{Y}-27008^{\mathrm{T}}$ & $79-9^{\mathrm{T}}$ & AF017412 \\
\hline & & Y-27009 & $79-3 \mathrm{~h}^{+}$ & \\
\hline & & Y-27010 & $79-4 \mathrm{~h}^{-}$ & \\
\hline Pichia meyerae & $7076^{\mathrm{T}}$ & $\mathrm{Y}-17236^{\mathrm{T}}$ & & U73578 \\
\hline Pichia mississippiensis & $7023^{\mathrm{T}}$ & YB-1294 ${ }^{\mathrm{T}}$ & & U74597 \\
\hline Pichia petersonii & $5555^{\mathrm{T}}$ & YB-3808 & & U73572 \\
\hline Pichia rhodanensis & $5518^{\mathrm{T}}$ & $Y-7854^{\mathrm{T}}$ & & U73571 \\
\hline Pichia veronae & $6591^{\mathrm{T}}$ & $Y-7818^{\mathrm{T}}$ & & U73576 \\
\hline Saccharomyces cerevisiae & $1171^{\mathrm{NT}}$ & $\mathrm{Y}-12632^{\mathrm{NT}}$ & & U44806 \\
\hline Schizosaccharomyces pombe & $356^{\mathrm{T}}$ & $\mathrm{Y}-12796^{\mathrm{T}}$ & & U40085 \\
\hline
\end{tabular}

*CBS, Centraalbureau voor Schimmelcultures, Delft, The Netherlands; NRRL, Agricultural Research Service Culture Collection, National Center for Agricultural Utilization Research, Peoria, IL, USA; UCD-FST, Department of Food Science and Technology, University of California, Davis, CA, USA.

nucleati $40 \cdot 3 \mathrm{~mol} \%$. Habitatio ad corticem putrescens arborum Hawaiiensis. Typus: stirps UCD-FST 79-9 ex cortex Tetraplasandrae sp. isolata est. In collectione zymotica Centraaalbureau voor Schimmelcultures, Delphi Batavorum sub no. CBS $8557^{\mathrm{T}}$ deposita est.

\section{Description of the type strain of Pichia lachancei sp. nov.}

Pichia lachancei (la.chan'cei. L. masc. gen. lachancei of Lachance, honouring M.-A. Lachance, a systematist and biologist of yeasts).

In YM (Difco) liquid medium after $5 \mathrm{~d}$ at $30^{\circ} \mathrm{C}$, the cells are ovoid to elongate or short cylindrical, $3-5 \times$ 4-12 (sometimes 16) $\mu \mathrm{m}$, single, in pairs and small clusters, reproducing by multilateral budding; a sediment is formed and a very thin, creeping pellicle. The streak culture on malt agar after 1 month at $25^{\circ} \mathrm{C}$ is greyish, butyrous to pasty, umbonate, rugose, semiglossy, pseudomycelial border. On cornmeal agar after 2 weeks, a well-developed pseudomycelium is present. Cells are heterothallic. On dilute vegetable agar $(1: 4)$, four hat-shaped spores are formed which are rapidly liberated from the asci upon maturity. Mating type segregation results in two $\mathrm{h}^{+}$and two $\mathrm{h}^{-}$spores. Glucose and sucrose are fermented; raffinose is very slowly fermented. The following carbon compounds are assimilated: glucose, sucrose, cellobiose, raffinose, D-xylose, L-rhamnose, ethanol, glycerol, D-mannitol (slowly), D-glucitol, salicin, methyl $\beta$-D-glucoside, glucono- $\delta$-lactone, lactate, succinate, citrate and ethyl acetate. The following are not assimilated: galactose, L-sorbose, maltose, trehalose, lactose, melibiose, melezitose, inulin, soluble starch, L-arabinose, D-arabinose, D-ribose, i-erythitol, ribitol, galactitol, methyl $\alpha$ D-glucoside, 2-ketogluconate, 5-ketogluconate, mesoinositol, glucosamine, $\mathrm{N}$-acetyl-D-glucosamine, hexadecane, 2-propanol and acetone. $\mathrm{KNO}_{3}$ and $\mathrm{NaNO}_{2}$ are not utilized as sole sources of nitrogen; ethylamine, cadaverine and L-lysine are utilized. Does not grow in vitamin-free medium. Grows in amino-acid-free medium. Does not grow in the presence of $100 \mu \mathrm{g}$ cycloheximide $\mathrm{ml}^{-1}$. Good growth on YM agar containing $5 \% \mathrm{NaCl}$; weak growth on YM agar containing $7.5 \% \mathrm{NaCl}$ and no growth at $10 \% \mathrm{NaCl}$. Does not grow in the presence of $50 \%(\mathrm{w} / \mathrm{w})$ glucose. Grows at $30^{\circ} \mathrm{C}$; no growth at $37^{\circ} \mathrm{C}$. Does not hydrolyse casein or gelatin. Does not produce urease or lipolytic activity. Diazonium Blue B reaction is negative. Nuclear DNA base composition $40.3 \mathrm{~mol} \%$ (buoyant density method). Habitat: moist rotting bark of Tetraplasandra hawaiiensis on the island of Hawaii. The type strain is UCD-FST $79-9^{\mathrm{T}}$ which has been 


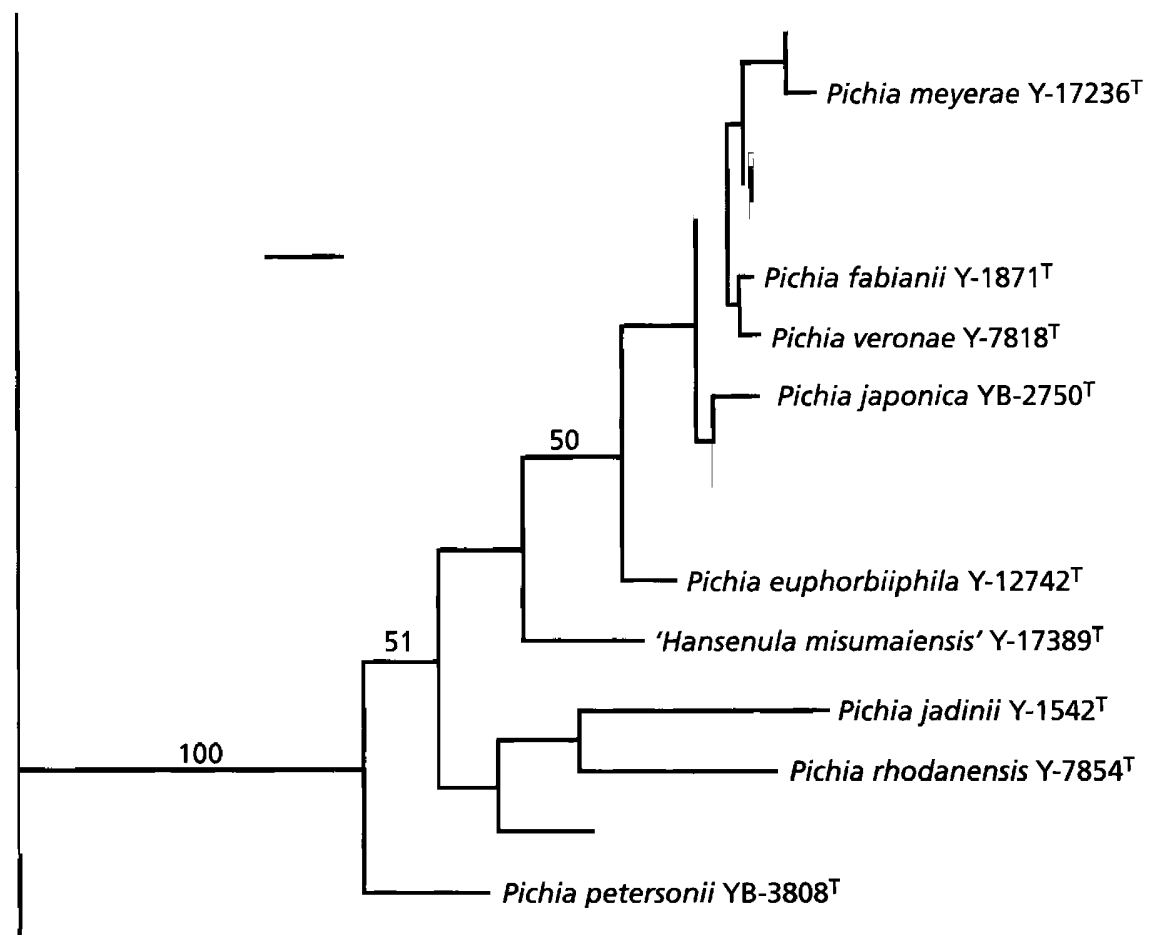

Schizosaccharomyces pombe $\mathrm{Y}-12796^{\top}$

\begin{abstract}
Fig. 1. Phylogenetic tree of Pichia lachancei and related species. The phylogram was calculated from divergence in LSU region $D 1 / D 2$ and represents the single most parsimonious tree derived from maximum-parsimony analysis. Branch lengths are proportional to nucleotide differences as indicated on the marker bar. Numbers given on branches are the percentage of frequencies with which a given branch appeared in 100 bootstrap replicates. Frequencies under $50 \%$ are not given. Tree length $=389$, consistency index $(\mathrm{Cl})=0.697$, homoplasy index $(\mathrm{HI})=0.303$, retention index $(\mathrm{RI})=0.516$ and rescaled consistency index $(R C)=0.360$. Each species is represented by the type $(T)$ or neotype (NT) strain. Strain designations are NRRL numbers. The outgroup species in the analysis was Schizosaccharomyces pombe.
\end{abstract}

deposited in the American Type Culture Collection as strain ATCC $201914^{\mathrm{T}}$, in the Centraalbureau voor Schimmelcultures, Delft, The Netherlands as strain CBS $8557^{\mathrm{T}}$ and in the ARS Culture Collection, National Center for Agricultural Utilization Research, Peoria, Illinois, USA as NRRL Y-27008 ${ }^{\mathrm{T}}$. Strains of Pichia lachancei isolated during two expeditions to Hawaii and their sources are given in Table 1. Based on rearing records of Montgomery (1975), it is assumed that $P$. lachancei is vectored by one or several picture-winged Drosophila species that use the three substrates indicated in Table 1 as larval breeding sites or feeding sites on the island of Hawaii. Most of the isolates of $P$. lachancei were asporogenous upon isolation, which was attributed to their haploid heterothallic state. From a single diploid ascus of strain UCD-FST 79-9 $9^{\mathrm{T}}$, four spores (two $\mathrm{h}^{+}$and two $\mathrm{h}^{-}$) were isolated which are represented by strains 79-10 to 7913 (Table 1). By using these mating types, other strains were identified as haploid mating types among the isolates (strains 79-2 to 79-5) but many strains did not react with either of the two mating types (indicated by unknown in Table 1). These could represent diploid strains that had lost the ability to sporulate, a common phenomenon with Pichia species in culture collections.
The phenotype of the asporogenous strains was identical to that of the type strain.

\section{ACKNOWLEDGEMENTS}

We are indebted to Martin W. Miller for his help in collecting field samples and to Christie Robnett for technical assistance with rDNA sequencing.

\section{REFERENCES}

Barnett, J. A., Payne, R. W. \& Yarrow, D. (1990). Yeasts: Characteristics and Identification, 2nd edn. Cambridge: Cambridge University Press.

Kurtzman, C. P. (1984). Pichia Hansen. In The Yeasts - a Taxonomic Study, 3rd edn, pp. 295-378. Edited by N. J. W. Kreger-van Rij. Amsterdam: Elsevier.

Kurtzman, C. P. (1998). Pichia E. C. Hansen emend. Kurtzman. In The Yeasts - a Taxonomic Study, 4th edn, pp. 273-352. Edited by C. P. Kurtzman \& J. W. Fell. Amsterdam: Elsevier. Kurtzman, C. P. \& Robnett, C. J. (1997). Identification of clinically important ascomycetous yeasts based on nucleotide divergence in the $5^{\prime}$ end of the large-subunit (26S) ribosomal DNA gene. $J$ Clin Microbiol 35, 1216-1223.

Kurtzman, C. P. \& Robnett, C. J. (1998). Identification and 
phylogeny of ascomycetous yeasts from analysis of nuclear large subunit (26S) ribosomal DNA partial sequences. Antonie Leeuwenhoek 73, 331-371.

Montgomery, S. L. (1975). Comparative breeding site ecology and the adaptive radiation of picture-winged Drosophila (Diptera: Drosophilidae) in Hawaii. Proc Hawaii Entomol Soc 22, 65-103.

Price, C. W., Fuson, G. B. \& Phaff, H. J. (1978). Genome comparison in yeast systematics: delimitation of species within the genera Schwanniomyces, Saccharomyces, Debaryomyces, and Pichia. Microbiol Rev 42, 161-193.

Swofford, D. L. (1993). PAUP: phylogenetic analysis using parsimony, version 3.1.1. Illinois Natural History Survey, Champaign, IL, USA.

Yarrow, D. (1998). Methods for the isolation, maintenance and identification of yeasts. In The Yeasts - a Taxonomic Study, 4th edn, pp. 77-100. Edited by C. P. Kurtzman \& J. W. Fell. Amsterdam: Elsevier. 